\title{
Detection of Hepatitis $C$ virus and Human immunodeficiency virus in expatriates in Saudi Arabia by antigen-antibody combination assays
}

\author{
Alhusain J. Alzahrani ${ }^{1}$, Obeid E. Obeid ${ }^{1}$, Amein Al-Ali ${ }^{2}$, Burhan Imamwardi ${ }^{3}$ \\ ${ }^{1}$ Department of Microbiology, College of Medicine, King Faisal University, Dammam, Saudi Arabia \\ ${ }^{2}$ Department of Biochemistry, College of Medicine, King Faisal University, Dammam, Saudi Arabia \\ ${ }^{3}$ Department of Medical Laboratory Technology, College of Applied Medical Sciences, King Faisal University, Dammam, Saudi \\ Arabia
}

\begin{abstract}
Background: The simultaneous detection of antigen and antibody was originally described for the early detection of the human immunodeficiency virus (HIV). The same approach was applied to detect the hepatitis C virus (HCV). The aim of this work was to use the antigen and antibody combination assay for the detection of HCV and HIV infections in expatriates in Eastern Saudi Arabia.

Methodology: The study group $(\mathrm{N}=875)$ included expatriate workers of both sexes who were undergoing mandatory pre-employment testing. Detection of anti-HCV antibodies, HCV core antigen, HCV viral RNA, HIV antigens and antibodies was conducted using commercially available kits.

Results: Of the 875 samples that were screened for HCV-specific antibodies, four $(0.46 \%)$ tested positive (two from Pakistan, one from India, and one from the Philippines) and two (0.23\%) were equivocal (one from Egypt and one from Nepal). All four samples that were positive for HCV-specific antibodies also tested positive using HCV RNA assay and the HCV antigen-antibody combination assay. The two samples that were equivocal tested positive using the HCV RNA assay and the HCV antigen-antibody combination assay. Of the 875 samples that were tested for HIV antibodies, only one $(0.11 \%)$ sample gave repeatedly positive results. The same sample also tested repeatedly positive using the HIV combination assay. These results were subsequently confirmed by HIV western blot assay.

Conclusions: Our study indicates that the addition of antigen detection to the screening of HCV and HIV may lower the risk of transmission of these viruses in the host country and contribute to the overall control of HCV and HIV in Saudi Arabia.
\end{abstract}

Key words: HCV, HIV, expatriates

J Infect Developing Countries 2009; 3(3):235-238.

Received 18 October 2008 - Accepted 5 January 2009

Copyright (C) 2009 Alzahrani et al. This is an open-access article distributed under the Creative Commons Attribution License, which permits unrestricted use, distribution, and reproduction in any medium, provided the original work is properly cited.

\section{Introduction}

Hepatitis $\mathrm{C}$ virus (HCV) is a small encapsulated positive strand RNA member of the Flaviviridae family. $\mathrm{HCV}$ is known for its aetiological role in chronic non-A, non-B viral hepatitis, liver cirrhosis and hepatocellular carcinoma. In addition, the virus has also been implicated in a number of extra-hepatic "autoimmune" disease manifestations [1]. At present, approximately 200 million people worldwide are infected with HCV [2]. The diagnosis of $\mathrm{HCV}$ is based on detecting either anti-HCV antibody by enzyme linked immunosorbent assay (ELISA) or HCV-RNA by polymerase chain reaction (PCR) [3]. More recently, $\mathrm{HCV}$ core antigen assays have been developed and they have a comparable sensitivity to that shown by the PCR-based assay, with a mean detection difference of one to two days [4-6]. The simultaneous detection of antigen and antibody was originally described for the early detection of HIV infection [7]. Since then, the same approach was applied to HCV diagnosis [8-9].

HCV seroprevalence in Saudi blood donors is estimated to be $3.5 \%$, whereas its prevalence in patients on dialysis varies between $15 \%$ and $80 \%$ [10]. The most prevalent genotype of $\mathrm{HCV}$ in patients in Saudi Arabia is genotype 4 followed by genotypes $1 \mathrm{a}$ and $1 \mathrm{~b}$, whereas genotypes $2 \mathrm{a} / 2 \mathrm{~b}, 3,5$, and 6 are rare. Since the introduction of routine hepatitis B virus (HBV) vaccination in Saudi Arabia, the seroprevalence of $\mathrm{HBV}$ has significantly decreased [11-13].

Currently there are 40 million individuals in the world infected with the human immunodeficiency virus (HIV) [14-15]. The World Health Organization 
estimates that nearly 16,000 new infections occur worldwide each day [16]. HIV-1 has presented several unique challenges which have prevented the effective control of the virus. The incidence of HIV infection among adults in the Middle East is estimated to be $0.3 \%$. However, there was a significant increase of $20 \%$ in 2002 [17]. In 2000, the cumulative number of HIV-infected individuals in Saudi Arabia was estimated to be 1,100 with an adult rate of $0.01 \%$ [18-19].

Expatriates form the driving workforce in industry in the Gulf region. Expatriate preemployment testing for infectious diseases is mandatory in many countries, including Saudi Arabia. This requirement applies to all jobs and all age groups. Currently, assessment of HCV and HIV infections in expatriate workers in Saudi Arabia depend on the detection of the virus-specific antibodies. Detection of both virus-specific antigens as well as virus-specific antibodies minimizes the window period (time between acquiring an infection and documentation of positive laboratory results) and therefore reduces the risk of spreading the infection within the community. The aim of this work was to use an antigen-antibody combination assay for the detection of HCV and HIV infections in expatriate workers in Eastern Saudi Arabia.

\section{Materials and Methods}

Patients

The study group $(\mathrm{N}=875)$ included expatriate workers of both sexes who were undergoing mandatory pre-employment testing. Jobs included domestic workers (housekeepers), farm workers, labourers, and various other jobs. The expatriate workers included in this study were from India, Bangladesh, Pakistan, Indonesia, Sri Lanka, Nepal, Thailand, Sudan, Egypt, and the Philippines with a mean age of 30.4 years \pm 5 .

\section{Detection of anti-HCV antibodies}

Anti-HCV antibodies were assayed by a thirdgeneration ELISA kit (Axsym HCV version 3.0, Abbott Diagnostics, Chicago, Ill.) and HCV 3.0 ELISA kit (Ortho-Clinical Diagnostics, Raritan, N.J.). In addition, the recombinant immunoblot assay (RIBA HCV 3.0; Ortho-Clinical Diagnostics) was used as previously described and in accordance with the manufacturer's instructions $[6,10]$.

\section{Detection of $H C V$ core $A g$}

$\mathrm{HCV}$ core Ag assay (Ortho-Clinical Diagnostics) was used (including the neutralization protocol) according to the manufacturer's recommendations and as previously described $[6,10]$.

Simultaneous detection of HCV antibodies and antigen (HCV Ag/Ab Combination assay)

Simultaneous detection of $\mathrm{HCV}$ antigen and $\mathrm{HCV}$ antibodies for all specimens was conducted using Muresx $\mathrm{HCV} \mathrm{Ag} / \mathrm{Ab}$ combination assay (Abbott Murex, USA) according to the manufacturer's instructions. In brief, test specimens and control sera were incubated in wells for 60 minutes to allow for the binding of $\mathrm{HCV}$ core antigen and $\mathrm{HCV}$ antibodies. After washing, peroxidase labeled conjugate was added and the wells were further incubated for 60 minutes. Unbound conjugate was washed and the substrate was incubated for 30 minutes after which the reaction was stopped and the plate was read at $450 \mathrm{~nm}$ [6].

\section{HCV RNA assays (Qualitative)}

To detect HCV RNA, the STRP Hepatitis C Virus Genome Detection Kit (CinnaGen Inc., Tehran, Iran) was used according to the manufacturer's instructions. The steps involved RNA extraction, cDNA synthesis, and nested PCR techniques. The assay has a limit of detection of 100 copies of HCV genome per $\mathrm{ml}$ of serum.

\section{Detection of HIV antigen and antibodies}

Detection of HIV antibody and the simultaneous detection of $\mathrm{HIV}$-specific antigens and antibodies were performed using Abbott AxSym MIEA and Combo assay (Abbott Laboratories, USA) according to the manufacturer's recommendations. Positive results were confirmed by HIV western blot assay (DuPont Company, Wilmington, DE, USA) as recommended by the manufacturer.

\section{Results}

Detection of HCV antigen, antibodies and viral RNA

Of the 875 samples that were screened for HCVspecific antibodies, four $(0.46 \%)$ tested positive (two from Pakistan, one from India and one from the Philippines) and two (0.23\%) were equivocal (one from Egypt and one from Nepal). All four samples that were positive for $\mathrm{HCV}$-specific antibodies also tested positive using HCV RNA assay and the HCV antigen-antibody combination assay. The two samples that were equivocal tested positive using the HCV RNA assay and the HCV antigen-antibody combination assay. 


\section{Detection of HIV antigen and antibodies}

Of the 875 samples that were tested for HIV antibodies, only one $(0.11 \%)$ sample gave repeatedly positive results. The same sample also tested repeatedly positive using the HIV combination assay. These results were subsequently confirmed by HIV western blot assay.

\section{Discussion}

The globalization of business activity can lead to the movement of key employees and their dependants from country to country. Expatriates comprise an important but rarely studied subset of international travelers. Adult expatriates that come from countries where HCV and HIV are highly endemic may spread these infections in their host countries. Therefore, pre-employment testing is widely applied to expatriates.

Initial testing for $\mathrm{HCV}$ should be performed using sensitive third-generation enzyme immunoassays (EIA) licensed for detection of antiHCV. False negative anti-HCV EIA results may occur in HIV-infected persons with advanced immune suppression $\left(\mathrm{CD} 4<100 / \mathrm{mm}^{3}\right)$ and true negative EIA are common in the setting of acute $\mathrm{HCV}$ infection ( $<12$ weeks following acquisition) prior to seroconversion [20-21]. If serologic test results are negative and $\mathrm{HCV}$ infection is suspected due to elevated liver enzyme levels or risk factors such as intravenous drug usage or high-risk sex, HCV RNA testing should be performed. While a single detectable HCV RNA result is sufficient to confirm the diagnosis of active $\mathrm{HCV}$ infection, a single negative result cannot exclude active viremia because RNA levels might transiently decline below the limit of detection. Therefore, it is of paramount importance that testing should be repeated in the host country.

This report presents data on the use of an antigen-antibody combination assay for the detection of HCV and HIV infections in a cohort of expatriates in the Eastern Province of Saudi Arabia. Because antigenemia usually precedes specific formation of antibodies, detection of virus-specific antigen will narrow the window period, hence reducing the risk of spreading the infection within the community [22]. Currently, there is no published data on the use of an antigen-antibody combination assay in expatriate preemployment testing.

Of the 875 expatriate samples that were screened for HCV antibodies, four were positive (By ELISA and RIBA). This may indicate past infection by
$\mathrm{HCV}$. Because of the high propensity of $\mathrm{HCV}$ to persist (in up to $80 \%$ of cases), these individuals may spread HCV by the various modes mentioned earlier. Two samples were equivocal using the $\mathrm{HCV}$ antibody assay, but they tested positive using the HCV RNA assay and the HCV antigen-antibody combination assay. These two subjects may be in the early stages of HCV infection, where there is marked viremia and antigenemia or alternatively, they might have a chronic HCV infection. The antibody production to a given antigen is influenced by genetic factors that determine whether the individual is a high responder or low responder to the given antigen [23].

Mahaba et al. [24] described the prevalence of $\mathrm{HCV}$ in 8862 subjects from the Hail region, Saudi Arabia. The overall prevalence was found to be $5.1 \%$, with a very high prevalence among Egyptian expatriates $(26 \%)$. The relatively low prevalence of $\mathrm{HCV}$ in our study group may well be due to an improvement in the control the testing for infectious diseases in the home countries of the expatriates.

One subject had detectable HIV antibodies. Both conventional antibody assay and antigen-antibody combination assay gave similar results. The advantage of the combination assay is the detection of early infection. Hamdi \& Ibrahim [25] analyzed the prevalence of sexually transmitted diseases (STDs) in domestic workers in Jeddah, Saudi Arabia. They HIV seroprevalence in their study group was $19 \%$. Consequently, they concluded that preemployment screening is a viable means of identifying major STDs and communicable diseases. It was recommended that stringent measures should be adopted to prevent fraudulent reporting from laboratories and health care providers locally and from the home country of the expatriates.

Based on the data presented here and on data from previous publications [26-27], the addition of antigen detection to the screening of HCV and HIV may lower the risk of transmission of these viruses in the host country and contribute to the overall control of HCV and HIV in Saudi Arabia.

\section{Acknowledgment}

This work was supported by a grant from the Deanship of Scientific Research, King Faisal University, Saudi Arabia. The authors are also grateful for the technical assistance of Mr. Larry Brtholome and Mr. Hassan M Essa. 


\section{References}

1. Maheshwari A, Ray S, Thuluvath PJ (2008) Acute hepatitis C. Lancet 372: 321-32.

2. Lo Re V 3rd, Kostman JR, Amorosa VK (2008) Management complexities of HIV/hepatitis $\mathrm{C}$ virus coinfection in the twenty-first century. Clin liver dis 12 : 587-609.

3. Laperche S, Le Marrec N, Simon N, Bouchardeau F, Defer C, Maniez-Montreuil M, Levayer T, Zappitelli JP, Lefrere JJ (2003) A new HCV core antigen assay based on disassociation of immune complexes: an alternative to molecular biology in the diagnosis of early HCV infection. Transfusion 43: 958-962.

4. Aarons E, Grant P, Soldan K, Luton P, Tang J, Tedder R (2004) Failure to diagnose recent hepatitis $C$ virus infections in London injecting drug users. J Med Virol 73: 548-553.

5. Netski DM, Wang XH, Mehta SH, Nelson K, Celentano D, Thongsawat S, Maneekarn N, Suriyanon V, Jittiwutikorn J, Thomas DL, Ticehurst JR (2004) Hepatitis C virus (HCV) core antigen assay to detect ongoing HCV infection in Thai injection drug users. J Clin Microbiol 42: 1631-1636.

6. Alzahrani AJ (2008) Simultaneous Detection of Hepatitis C Virus (HCV) Core Antigen and Antibodies in Saudi drug Users Using a Novel Assay. J Med Virol 80: 603-606.

7. Balasubramanian A, Groopman JE, Ganju RK (2008) Underlying pathophysiology of $\mathrm{HCV}$ infection in HIVpositive drug users. J addic dis 27: 75-82.

8. Pawlotsky JM (2002) Use and interpretation of virological tests for hepatitis C. Hepatol 36: S65-73.

9. Schutten M (2008) Comparison of the Abbott Realtime HIV-1 and HCV viral load assays with commercial competitor assays. Exper rev molec diagnos 8: 369-377.

10. Alzahrani AJ (2005) Analysis of HCV antigenemia in Saudi drug users. Saudi Med J 26: 1645-1646.

11. Njoh J, Zimmo S (1997) Prevalence of antibodies to hepatitis $C$ virus in drug-dependent patients in Jeddah, Saudi Arabia. East African Med J 74: 89-91.

12. Shawky S, Ghabrah TM, Abalkhail BA, Soliman NK (2003) Hepatitis C infection among drug addicts. Saudi Med J 24: S133-S133.

13. Fathalla S, Al-Jama A, Badawy M, Sabry H, Awad O, Abdul-Aziz F, Elnajar M (2003) Prevalence of hepatitis $\mathrm{C}$ virus infection in the Eastern Province of Saudi Arabia DNA and second generation and supplemental EIA tests. Saudi Med J 24: S120-S121.

14. Merson MH, O'Malley J, Serwadda D, Apisuk C (2008) The history and challenge of HIV prevention. Lancet 372: 47588

15. Shen L, Siliciano RF (2008) Viral reservoirs, residual viremia, and the potential of highly active antiretroviral therapy to eradicate HIV infection. J Allergy \& Clin Immunol 122: 22-28.
16. Gupta GR, Parkhurst JO, Ogden JA, Aggleton P, Mahal A (2008) Structural approaches to HIV prevention. Lancet 372: 764-775.

17. Oelrichs R (2004) The subtypes of human immunodeficiency virus in Australia and Asia. Sex Heal 1: $1-11$.

18. Alrajhi AA (2004) Human immunodeficiency virus in Saudi Arabia. Saudi Med J 25: 1559-1563.

19. Madani TA, Al-Mazrou YY, Al-Jeffri MH, Al Huzaim NS (2004). Epidemiology of the human immunodeficiency virus in Saudi Arabia; 18-year surveillance results and prevention from an Islamic perspective. BMC Infec Dis 6: 4:25.

20. Courouce AM, Le Marrec N, Bouchardeau F, Razer A, Maniez M et al. (2000) Efficacy of HCV core antigen detection during the preseroconversion period. Transfusion 40: 1198-202.

21. Letowska M, Brojer E, Mikulska M, Gronowska A, Rosiek A (2004) Hepatitis C core antigen in Polish blood donors. Transfusion 44:1067-1071.

22. Takahashi M, Saito H, Higashimoto M, Atsukawa K, Ishii H (2005) Benefit of hepatitis $\mathrm{C}$ virus core antigen assay in prediction of therapeutic response to interferon and ribavirin combination therapy. J Clin Microbiol 43: 186-91.

23. Thio CL (2008) Host genetic factors and antiviral immune responses to hepatitis $\mathrm{C}$ virus. Clinic liver dis 12: 713-726.

24. Mahaba H, el-Tayeb Ael-K, Elbaz H (1999) The prevalence of antibodies to hepatitis $\mathrm{C}$ virus in Hail region, Saudi Arabia. J Egyp Pub Health Assoc 74: 69-80.

25. Hamdi SA, Ibrahim MA (2008) Sexually transmitted diseases in domestic expatriate workers in Jeddah, Saudi Arabia. Ann Saudi Med 17: 29-31.

26. Sickinger E, Jonas G, Yem AW, Goller A, Stieler M, Brennan C, Hausmann M, et al. (2008) Performance evaluation of the new fully automated human immunodeficiency virus antigen-antibody combination assay designed for blood screening. Transfusion 48:584-93.

27. Ansaldi F, Bruzzone B, Testino G, Bassetti M, Gasparini R, Crovari P, Icardi G (2006) Combination hepatitis C virus antigen and antibody immunoassay as a new tool for early diagnosis of infection. J Viral Hepat 13:5-10.

\section{Corresponding Author}

Dr. Obeid E. Obeid, Department of Microbiology, College of Medicine, King Faisal University, P.O. Box 2114, Dammam \# 31451, Saudi Arabia

Phone: 0096638577000-2005. Fax: 0096638575329

E mail: oobeid@yahoo.com

Conflict of interest: No conflict of interest is declared. 